\title{
Somatic and germinal growth of the infaunal brittle stars Amphiura filiformis and A. chiajei in response to organic enrichment
}

\author{
Mattias Sköld*, Jonas S. G. Gunnarsson \\ Göteborg University, Kristineberg Marine Research Station, S-450 34 Fiskebäckskil, Sweden
}

\begin{abstract}
The effects of a short-term organic enrichment on growth of the 2 brittle stars Amphiura filiformis (O. F. Müller) and Amphiura chiajei (Forbes) were studied in undisturbed sediment cores obtained from a coastal and an offshore site of the Kattegat and Skagerrak, and then maintained in the laboratory as microcosms. Growth was measured as arm regeneration (somatic growth) and oocyte size (germinal growth). Macrofaunal abundance and biomass were higher in the offshore sediment compared to the coastal site. Organic enrichment was studied by adding concentrated phytoplankton (diatoms) to mimic the sedimentation pulse of a spring bloom in terms of quality and quantity. The experiment was run for 2.5 mo (April to June 1993). Somatic growth of A. filiformis increased in response to the phytoplankton addition in the coastal site sediment but not in the offshore site sediment. Arm regeneration in A chiajei increased in both sediments in response to the food pulse. A positive correlation between regenerated arm length and oocyte size was obtained for both species. The results show that the brittle stars were capable of increasing their growth and gonad development in response to the short-term organic enrichment. The difference between sites also suggests negatively density dependent growth indicative of space or food competition in the densely populated offshore sediment
\end{abstract}

KEYWORDS: Regeneration - Oocyte size - Echinodermata Ophiuroidea - Eutrophication Kattegat Skagerrak - Microcosm

\section{INTRODUCTION}

The food supply to benthic organisms relies on the sedimentation of organic matter that is produced in the euphotic zone by primary producers. The seasonal cycle of phytoplankton production and sedimentation in the Kattegat-Skagerrak shows peaks in sedimentation of primary organic material during spring and autumn blooms and low inputs to the sediment during the rest of the year (Smetacek 1980). The most important energy input to the benthos occurs shortly after the spring bloom, when large amounts of diatom cells sediment out as aggregates (Smetacek \& Hendrikson 1985, Kiørboe et al. 1994). Diatoms have a high nutritive value due to a well-balanced content of essential

·E-mail: m.skold@kmf.gu.se fatty acids and amino acids (Tenore 1988). Sedimentation of the spring bloom takes only a few days creating a tight coupling between the pelagic and benthic systems (Graf et al. 1982, Davies \& Payne 1984). The spring pulse of organic matter thus constitutes a labile, immediately available and highly nutritive food source for the benthos (Balzer 1984, Henrichs \& Doyle 1986 Lopez \& Levinton 1987, Marsh \& Tenore 1990).

An essential question is how benthic organisms respond to the seasonal fluxes of organic matter sedimentation. Several field studies have focused on the importance for the benthos of this short-term organic enrichment. Following sedimentation events in the Kiel Bight, Graf et al. (1982, 1983) observed an increase in bacterial activity and meiofaunal biomass, but no convincing effects on macrofauna. In bivalves, an increase in somatic growth and gonad development has been directly related to seasonal fluctuations in 
food availability (Ansell 1974, Ankar 1980). Sedimentation from the spring bloom was found to be the main regulating factor for the somatic growth and development of reproductive tissue of benthic macrofauna in the northern Øresund (Christensen \& Kanneworff 1985, Kanneworff \& Christensen 1986, Nicolaisen \& Christensen 1986).

Field observations of short-term sedimentation events and their benthic-pelagic coupling are complicated by the overwhelming role of the hydrography. Metabolic processes such as growth rate also depend on temperature; however, several studies have shown that food supply clearly dominated temperature affects on metabolism (Christensen \& Kannewororff 1985, Graf 1992). In experimental studies with undisturbed sediments a known quantity and quality of organic matter is supplied to natural benthic assemblages and then the effects of the added organic matter can be evaluated without the influences of hydrography and temperature (Kelly \& Nixon 1984, Grassle et al. 1985, Graf 1987, Duineveld et al. 1991, 1992, van Duyl et al. 1992, Webb \& Montagna 1993, Osinga et al. 1995). Processes such as nutrient fluxes, oxygen consumption and microbial abundance have, however, been more studied than the effects on macrofaunal growth.

The Kattegat and the Skagerrak have during the last decades experienced increased anthropogenic inputs of nutrients (Rosenberg et al. 1990), and primary production is estimated to have increased from less than 100 to about $200 \mathrm{~g} \mathrm{C} \mathrm{m}^{-2} \mathrm{yr}^{-1}$ since the 1950 s (Richardson \& Heilmann 1995). In areas where the water mixing is efficient, an increase of benthic macrofaunal abundance and biomass, especially of the dominant brittle star Amphiura filiformis, has been observed and correlated to this eutrophication (Pearson et al. 1985, Pearson \& Rosenberg 1987, Josefson 1990, Josefson et al. 1993). A. filiformis populations are known to be stable over several years in density and size structure and to have low rates of recruitment $\left(\mathrm{O}^{\prime} \mathrm{Connor}\right.$ et al. 1983, Duineveld \& Noort 1986). However, it is not known how brittle star populations respond to short-term sedimentation events of highly nutritive organic matter, such as after the spring bloom. Increase in biomass of longlived species can only be correlated to increased food input if food is a limiting resource and if no densityindependent factors such as predation regulate population size and biomass. Harris (1989) showed theoretically that intraspecific injury models can lead to population stability provided that survival or reproduction is affected. Sub-lethal predation on A. filiformis is indeed high (Bowmer \& Keegan 1983, Duineveld \& Noort 1986, Munday 1993, Sköld \& Rosenberg 1996), suggesting that changes in predation intensity may also be a factor contributing to the explanation of increased biomasses.
The aim of this study was to investigate if short-term organic enrichment, of the same magnitude and quality as a spring bloom, stimulates growth of the common infaunal brittle stars Amphiura filiformis (O. F Müller) and Amphiura chiajei (Forbes), the latter being a strict deposit feeder, while A. filiformis can switch from deposit to suspension feeding (Buchanan 1964). We also compared the growth response of these brittle stars in undisturbed sediment cores from 2 sites of the Skagerrak-Kattegat differing in macrofaunal abundance and biomass.

\section{MATERIAL AND METHODS}

Site descriptions and sampling. Coastal site sediments were collected on the Swedish west coast $\left(57^{\circ} 40.31^{\prime} \mathrm{N}, 11^{\circ} 41.39^{\prime} \mathrm{E}\right.$, Fig. 1) at $21 \mathrm{~m}$ depth on March 9, 1993. The offshore site sediments were collected in the south east Skagerrak $\left(57^{\circ} 57.40^{\prime} \mathrm{N}\right.$, $11^{\circ} 09.00^{\prime}$ E, Fig. 1), at a depth of $90 \mathrm{~m}$ on March 11 , 1993. Eight sediment cores were taken from each site with a modified USNEL box-corer $\left(0.25 \mathrm{~m}^{2}\right)$, with a fitted internal plexiglass liner to provide undisturbed sediments according to the method of Berge et al. (1986). The box-cores were handled cautiously to minimise resuspension and aerated during transport

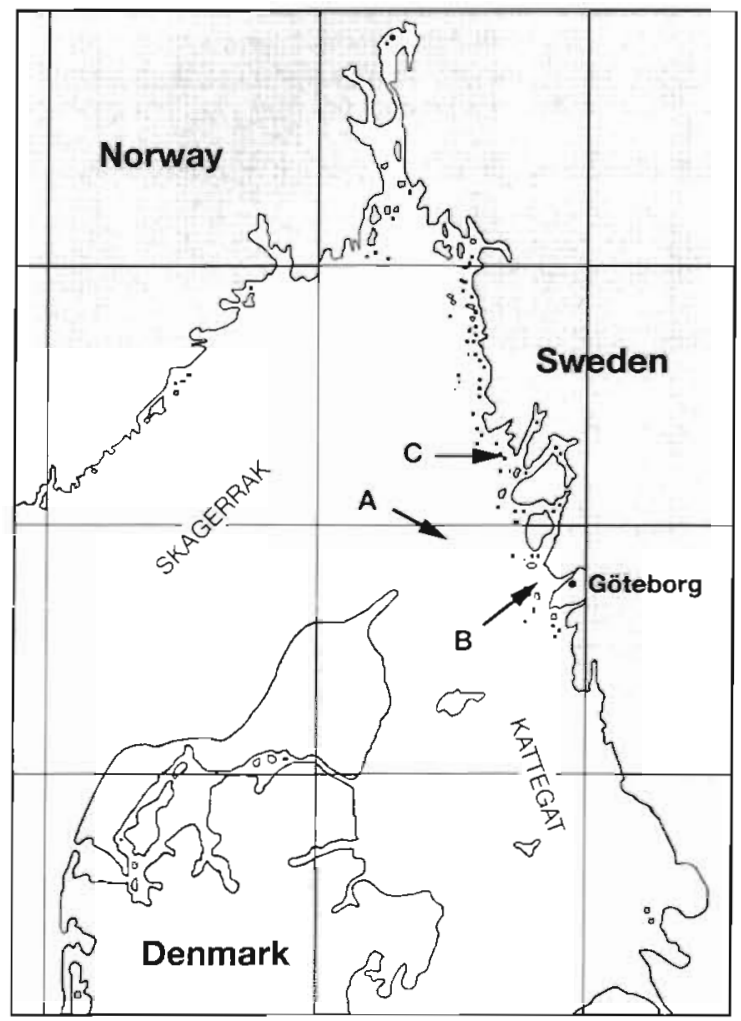

Fig. 1. Sampling sites: (A) Offshore site. (B) coastal site and (C) site where brittle stars added to the experiment were collected 
to the Marine Research Station Solbergstrand, Norwegian Institute for Water Research, where the experiment was carried out.

Three box-cores from each site were collected as above to determine macrofaunal abundance and biomass. The samples were sieved ( $1 \mathrm{~mm}$ mesh size), the macrofauna preserved in $70 \%$ ethanol, and animals later sorted at 6 times magnification. Total biomass was determined as ethanol wet weight including shells.

In order to avoid genetic differences and pre-adaptation to the sediment conditions, the brittle stars measured in the experiment (Amphiura filiformis and Amphiura chiajei) were collected at an independent site west of Gullmarsfjorden $\left(58^{\circ} 17.80^{\prime} \mathrm{N}, 11^{\circ} 23.70^{\prime} \mathrm{E}\right)$ at a depth of $25 \mathrm{~m}$ on March 10, 1993. The ophiuroids were sampled with a box-corer $(30 \times 30 \mathrm{~cm})$, immediately collected from the sediment cores by gentle rinsing to avoid breaking of arms and transported to the laboratory in aerated thermo-tanks.

Sediment characteristics, contaminants and toxicity. Three sub-samples of the surface sediment $(0$ to $2 \mathrm{~cm})$ of each box-core were taken at the start of the experiment and kept frozen $\left(-20^{\circ} \mathrm{C}\right)$ for analyses of total organic carbon (TOC), contaminants and toxicity. After freeze-drying and removal of inorganic carbon according to Hedges \& Stern (1983), TOC ( $n=8$ ) was analysed with a Carlo Erba NA $1500 \mathrm{C} / \mathrm{N}$ analyser. Two different standardised toxicity tests were run on sediment samples from each site. Toxicity testing with Nitocra spinipes (96 $\mathrm{h} \mathrm{LC}_{50}$ at a highest concentration of $3.2 \mathrm{~g}$ wet wt diluted to $10 \mathrm{ml}$ ) was performed according to Swedish standard (SIS 1985) and Dave \& Nilsson (1994) on 3 replicate sediment samples from each site with 5 parallel runs. A Microtox ${ }^{\oplus}$ test was performed according to Brouwer et al. (1990) on 3 replicate sediment samples, with 2 parallel runs at $1.0 \mathrm{~g}$ wet wt per $9 \mathrm{ml} 2 \% \mathrm{NaCl}$ solution. Contaminants were analyzed by gas chromatography according to the method of Brorström-Lundén (1995) on 1 sample from each site.

Experimental set-up. The 16 box-cores were placed in a darkened room and connected in a flow-through style to a header tank receiving unfiltered $40 \mathrm{~m}$ deep fjord water. Temperature $\left(6.2\right.$ to $7.6^{\circ} \mathrm{C}$ ) and salinity ( $\left.34 \mathrm{psu}\right)$ of the incoming water were continuously registered during the experiment (Fig. 2), A semi-laminar flow over the surface of the box-cores was created by leading the water under 2 horizontal bars placed $2.5 \mathrm{~cm}$ above the sediment as in Skei et al. (1987). Flow was adjusted by observing the fate of a tracer (milk) and flow rate was regulated to ca $1.21 \mathrm{~min}^{-1}$, creating a bottom current of ca $0.17 \mathrm{~cm} \mathrm{~s}^{-1}$. Photographs of the surface and the upper sediment profile of each box-core were taken regularly in order to survey animal activity and to estimate the evolution of the sediment redox potential discontinuity (RPD) layer (Fenchel \& Riedl 1970).

Addition of experimental brittle stars. Brittle stars were defined as adults by having an oral width $>2.1 \mathrm{~mm}$ (Sköld et al. 1994). An ocular micrometer was used to measure oral width to a precision of $0.1 \mathrm{~mm}$ according to the method of $O^{\prime}$ Connor et al. (1983). Before addition, the first arm clockwise to the madreporite of each animal was cut between the seventh and eighth arm segment counted from the mouth. Amphiura filiformis ( $\mathrm{n}=5$ ) were added on March 26 and Amphiura chiajei ( $n=4$ ) on April 6, and the experiment terminated between June 8 and 13 .

Organic enrichment. Organic enrichment was provided to 4 box-cores from each site by adding weekly batches of concentrated phytoplankton on 4 occasions. The first 3 pulses were taken from a concentrated mono-culture of the marine diatom Phaeodactylum tricornutum grown in a $600 \mathrm{l}$ tank filled with filtered deep water and growth medium. The culture was left to sediment out and aggregated algae were collected
Fig. 2. Salinity (psu) and temperature $\left({ }^{\circ} \mathrm{C}\right)$ of incoming Oslofjord water $(-40 \mathrm{~m})$ from March to June 1993

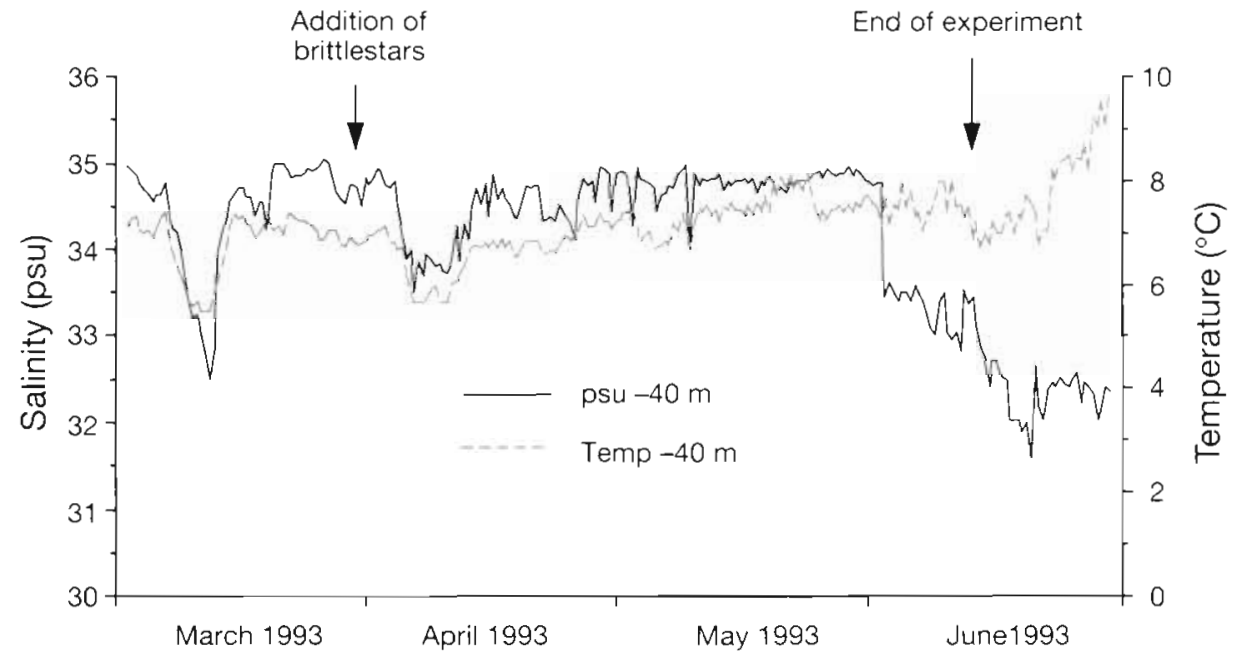


at the bottom. The fourth batch was collected in May by plankton haulings in the Oslofjord, mainly consisting of Skeletonema costatum, which were left to aggregate for $24 \mathrm{~h}$. TOC and nitrogen content of each batch was determined by filtering 5 to $15 \mathrm{ml}$ of the algae with GF/C filters. TOC and total nitrogen (TN) were measured as described above for the sediments. An average $\mathrm{C}: \mathrm{N}$ ratio of 6.5 was obtained. The addition of organic material was performed by first stopping the water flow, then adding the concentrated suspension via the water inlet and letting it sediment out for 2 to 4 h. The amount of organic material leaving the boxcores when the water flow was reinstated was estimated by collecting 11 of outflowing water in a time series $(0,3,5,8,11$ and 14 min) from each box-core. The water was filtered (GF/C filters) and particulate matter dry weights (held at $60^{\circ} \mathrm{C}$ till constant weight) were plotted against time. The time series integrated dry weights, with the normal dry weights of the outflowing water (sampled before organic addition) subtraced, were considered to represent the loss of organic material. Control levels of particular matter of the incoming water were $1.01(\mathrm{SD}=0.71) \mathrm{mg}$ dry $\mathrm{wt} \mathrm{l}^{-1}$ and $0.36(\mathrm{SD}=0.21) \mathrm{mg}$ ash-free dry wt $\mathrm{I}^{-1}$. Organic carbon was measured to ca $48 \%$ of the dry weight giving a mean loss of added organic material of $9.7 \%$. The total concentration of organic material added to the treated box-cores (i.e. the sum of the 4 pulses) was estimated to be $16.8 \mathrm{~g}$ org $\mathrm{C} \mathrm{m}^{-2}$.

Measurements of arm regeneration and oocyte size. At the end of the experiment, the macrofauna was sieved out ( $1 \mathrm{~mm}$ mesh size), all brittle stars were examined, and the 2 Amphiura species with a regenerated arm at the point of amputation were recorded alive by video and then preserved with $10 \%$ formalin buffered sea water. The experimental brittle stars were identified by size (i.e. oral width) and the position of the regenerated arm. Regenerated arm length and disk area were measured by image analysis (software package NIH Image 1.50). Oocyte area of Amphiura filiformis and Amphiura chiajei was measured by Confocal Laser Scanning Microscopy (CLSM) (Molecular Dynamics) with a Nikon Planapo 20/0.75 objective lens. Whole brittle stars were put in Herr's clearing fluid (Herr 1971, Fredriksson 1991) after being transferred through a gradient of alcohols $(70,95$ and $99.5 \%$ ethanol). Herr's clearing fluid made the gonads transparent within 12 to $15 \mathrm{~h}$. Gonads were then carefully dissected from the brittle stars, transferred to a cavity slide with some droplets of Herr's fluid, and a cover glass was added. Sex was determined and female gonads were sectioned 10 times in $5 \mu \mathrm{m}$ steps. No staining was necessary since the oocytes displayed autofluorescence at a wavelength of $488 \mathrm{~nm}$. Each oocyte was then examined and considered sectioned through the middle when the maximum area, the nucleus and the nucleolus were displayed on the same section. Oocyte area was then measured by image analysis (software package Image Space by Molecular Dynamics) on 10 oocytes from 3 gonads of each individual. Stage of maturity was determined according to Fenaux (1970) and Bowmer (1982).

Statistics. Data were analysed by factorial analysis of variance (ANOVA) with regenerated arm length or disk area of the brittle star species as dependent variables. Site (coastal and offshore) and treatment (control and organic enrichment) were considered as fixed factors and were tested over the nested factor (aquarium) mean square. If the first order interaction was significant, multiple comparisons were performed using Student-Newman Keul's test (SNK-test) (Sokal \& Rohlf 1995). To fulfill the criterion of homoscedasticity, disk area was corrected by $x^{1 / 2}$ transformations since the variance was approximately equal to the mean (Sokal \& Rohlf 1995). All data were tested for presence of gross heterogeneity of variances with Cochrans $C$-test $(\alpha=0.05)$ (Snedecor \& Cochran 1967).

As an unbalanced and small number of females of each species was recovered, no ANOVA was run on these data. Instead, correlations between mean oocyte diameter (calculated from the area) and arm length were performed on the females of Amphiura filiformis and Amphiura chiajei. Trends were considered significant when ( $\alpha=0.05$ for the product moment correlation coefficient r (Sokal \& Rohlf 1995).

\section{RESULTS}

\section{Sediment and macrofauna characteristics of the sampling sites}

Macrofaunal densities and biomass were about 3 and 11 times higher in the offshore sediment in comparison to the coastal sediment, respectively. The most abundant species overall in both sediments was Amphiura filiformis with an exceptionally high density of about 3350 ind $\mathrm{m}^{-2}$ in the offshore compared to $350 \mathrm{ind} . \mathrm{m}^{-2}$ in the coastal sediment (Table 1). Levels of contaminants and organic carbon did not vary considerably between sites. Neither the toxicity testing with Nitocra spinipes for the sediments nor the Microtox ${ }^{\otimes}$ test showed any significant toxicity or difference between sites

\section{Response to organic enrichment}

Each addition of organic matter to the box-cores caused an immediate active response of the brittle stars The organic material sedimented out into a fluffy layer 
on the sediment surface, in which the brittle stars were seen sweeping and curling their arms around aggregates to bring them downwards to their mouth. After 3 to $4 \mathrm{~h}$ all algal material had disappeared from the surface of the offshore sediment, while brown patches of aggregates were still visible on the coastal sediment surface until the end of the experiment. Surface photographs of the box-cores revealed no differences in time, indicating that the benthic communities remained healthy throughout the experiment. No differences in RPD layer were observed from the photos of the aquaria walls, indicating that no deterioration in sediment oxidation potential due to organic enrichment or experimental conditions took place.

\section{Difference between treatments and site}

As significant interactions between treatment and site were found for arm length and disk size of Amphiura filiformis and disk size of Amphiura chiajei (Table 2a, b \& d) comparisons were made on the sites separately. For the coastal site sediment both species showed an increase in disk area when dosed with organic enrichment compared to the control (SNK-test $\mathrm{p}<$ 0.05); however, the SNK test failed to detect any difference for arm length in $A$. filiformis, but the pattern was similar with an increased growth due to the treatment in the coastal site sediment (Fig. 3A). For the offshore site sediment no treatment effect was found either for disk size and arm length in $A$. filiformis, or for disk size in $A$. chiajei. Analyses of arm length of $A$. chiajei (Table $2 c$ and Fig. 3C) showed increased arm length for the organic enrichment compared to the control, but no difference between sites.

\section{Differences between Amphiura filiformis and Amphiura chiajei}

Amphiura chiajei regenerated only ca $20 \%$ of the increase observed for Amphiura filiformis (Table 3). Maturation stage of oocyte development at the time of the experiment was also different between species. A. filiformis was in prematuration to shedding phases (Fig. 4A), while A. chiajei was in shedding to post shedding phases with 2 obvious size groups of eggs visible in most of the gonads (Fig. 4B). Because of the unbal- anced numbers of individual females of both species, and because of the 2 size classes found in $A$. chiajei, no ANOVA was performed on egg sizes. Instead trend analysis, with mean oocyte diameter (transformed from measured area) as the independent variable and regenerated arm length as the dependent variable, were performed for both species. Trends were positive $(\mathrm{n}=31$, $\mathrm{r}=0.53, \mathrm{p}<0.05$ for $\mathrm{A}$. filiformis; $\mathrm{n}=26, \mathrm{r}=0.49, \mathrm{p}<0.05$ for $A$. chiajeil indicating that oocyte size had increased with organic enrichment.

\section{DISCUSSION}

Microcosms with undisturbed natural sediment cores offer an increased possibility in understanding how benthic fauna may react to environmental changes, including or excluding factors that can explain by themselves or in an interactive way biological variability. The generality of influences on growth by spatial variation in sediment type and quality was not tested in this experiment since the type of sites from which the sediments were collected was not randomly chosen and replicated. The factor treatment (control and organic enrichment) used here is easier to interpret since observed effects are dependent only on the phytoplankton addition. 
Table 2. Factorial ANOVA with sites (coastal and offshore) and treatment (organic enrichment and control) as main effects and aquaria as nested factor; $\mathrm{p}<0.05 ; \cdots p<0.01$, ns: not significant

\begin{tabular}{|c|c|c|c|c|c|c|}
\hline Source of variation & $\mathrm{df}$ & $\begin{array}{l}\text { Sum of } \\
\text { squares }\end{array}$ & $\begin{array}{l}\text { Mean } \\
\text { square }\end{array}$ & $F$ & $\mathrm{p}$ & Error term \\
\hline \multicolumn{7}{|c|}{ (a) Dependent: arm lenyth of Amphiura filiformis } \\
\hline Site & 1 & 10.123 & 10.123 & 0.803 & $0.3877 \mathrm{~ns}$ & Aquarium \\
\hline Treatment & 1 & 7.275 & 7.275 & 0.577 & $0.4620 \mathrm{~ns}$ & Aquarium \\
\hline Site $\times$ Treatment & 1 & 86.815 & 86.815 & 6.889 & $0.0222^{*}$ & Aquarium \\
\hline Aquarium (Site, Treatment) & 12 & 151.228 & 12.602 & 1.317 & $0.2529 \mathrm{~ns}$ & Residual. \\
\hline Residual & 35 & 334.905 & 9.569 & & & \\
\hline \multicolumn{7}{|c|}{ (b) Dependent: $x^{1 / 2}$ transformed disk area of Amphura filiformis } \\
\hline Site & 1 & 0.361 & 0.361 & 2.253 & $0.1592 \mathrm{~ns}$ & Aquarium \\
\hline Treatment & 1 & 0.851 & 0.851 & 5.303 & $0.0400^{\bullet}$ & Aquarium \\
\hline Site $\times$ Treatment & 1 & 2.046 & 2.046 & 12.757 & $0.0038^{\cdots}$ & Aquarium \\
\hline Aquarium (Site, Treatment) & 12 & 1.925 & 0.16 & 0.633 & $0.8000 \mathrm{~ns}$ & Residual \\
\hline Residual & 35 & 8.874 & 0.254 & & & \\
\hline \multicolumn{7}{|c|}{ (c) Dependent: arm length of Amphiura chiajei } \\
\hline Site & 1 & 1.39 & 1.39 & 2.413 & $0.1463 \mathrm{~ns}$ & Aquarium \\
\hline Treatment & 1 & 5.603 & 5.603 & 9.727 & $0.0089 \cdots$ & Aquarium \\
\hline Site $\times$ Treatment & 1 & 0.004 & 0.004 & 0.007 & $0.9349 \mathrm{~ns}$ & Aquarium \\
\hline Aquarium (Site. Treatment) & 12 & 6.912 & 0.576 & 0.907 & $0.5475 \mathrm{~ns}$ & Residual \\
\hline Residual & 65 & 24.652 & 0.379 & & & \\
\hline \multicolumn{7}{|c|}{ (d) Dependent: $x^{1 / 2}$ transformed disk area of Amphiura chaajei } \\
\hline Site & 1 & 0.386 & 0.386 & 0.996 & $0.3379 \mathrm{~ns}$ & Aquarium \\
\hline Treatment & 1 & 1.722 & 1.722 & 4.446 & $0.0567 \mathrm{~ns}$ & Aquarium \\
\hline Site $\times$ Treatment & 1 & 3.426 & 3.426 & 8.848 & $0.0116^{\circ}$ & Aquarium \\
\hline Aquarium (Site, Treatment) & 12 & 4.647 & 0.387 & 1.781 & $0.0836 \mathrm{~ns}$ & Residual \\
\hline Residual & 65 & 24.652 & 0.379 & & & \\
\hline
\end{tabular}
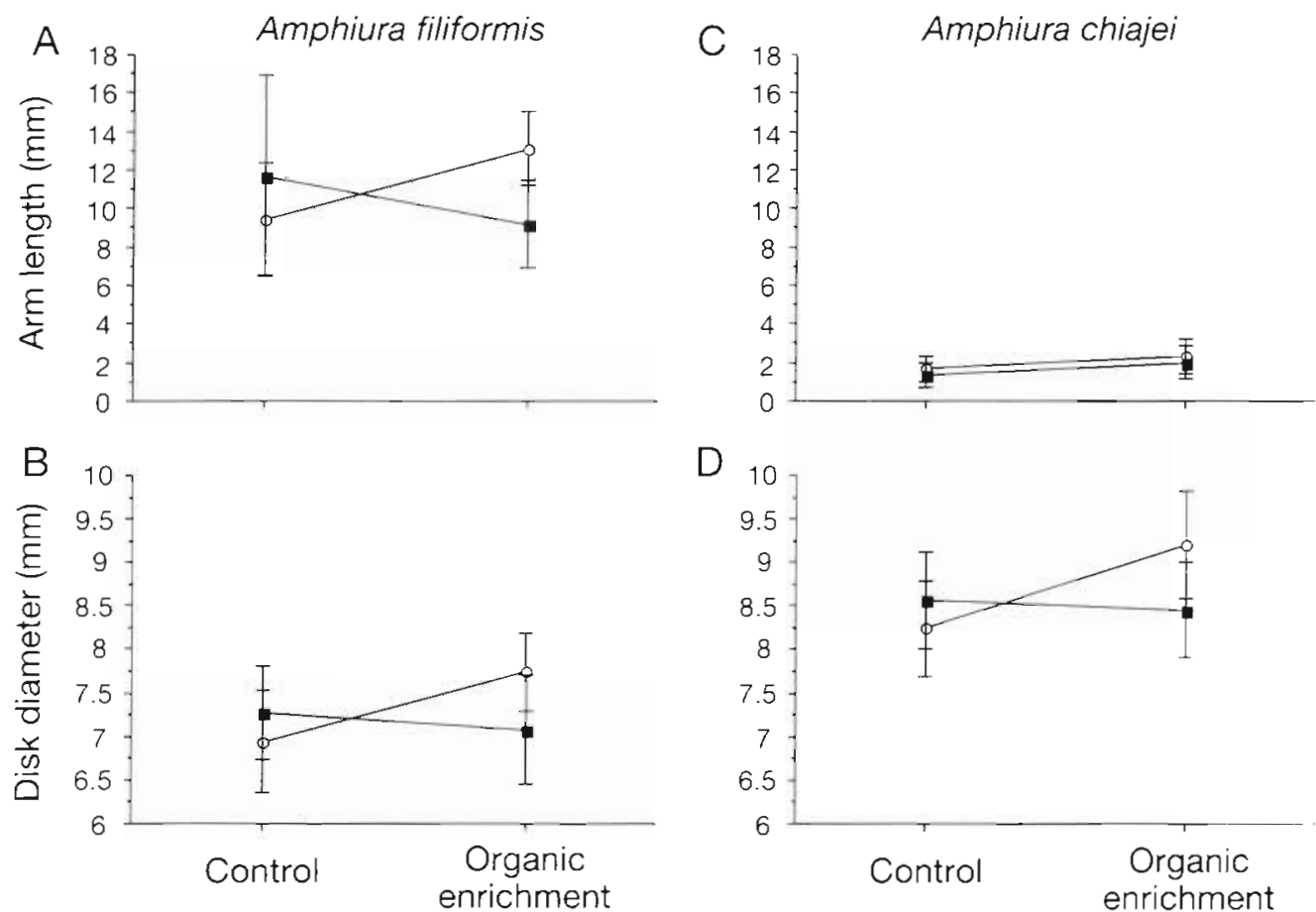

Fig. 3. Interaction plots of arm length and disk diameter (converted from measurements of disk area). (0) Coastal site; (a) offshore site. Error bars are standard deviation. (A) Arm length ot Amphiura fillformis. (B) Disk diameter of $A$. filiformis. (C) Arm length of A. chiajei. (D) Disk djameter of $A$. chirijeil 
Table 3. Mean regeneration and standard deviation (SD) in mm and dry weights. Dry weights $(Y)$ are converted from arm length $(X)$ by the biometrical relationship for regenerated Amphiura flliformis arms: $Y=0.010564 X^{12878}$ (Skold et al. 1994). Regeneration rates are calculated by dividing regenerated arm lengths by $77 \mathrm{~d}$ for A. filiformis and $66 \mathrm{~d}$ for Amphiura chiajei. Organic enrichment: box-core treated with aggregated phytoplankton. Control: no organic enrichment

\begin{tabular}{|c|c|c|c|c|c|c|}
\hline Site & Treatment & $\begin{array}{l}\text { Number of } \\
\text { individuals (n) }\end{array}$ & $\begin{array}{l}\text { Mean regenerated } \\
\text { arm length }(\mathrm{mm})\end{array}$ & $\begin{array}{l}\mathrm{SD} \\
(\mathrm{mm})\end{array}$ & $\begin{array}{l}\text { Regeneration rate } \\
\left(\mathrm{mm} \text { arm } \mathrm{d}^{-1}\right)\end{array}$ & $\begin{array}{c}\text { Mean regenerated } \\
\text { dry wt }(\mathrm{g})\end{array}$ \\
\hline \multicolumn{7}{|c|}{ Amphiura filiformis } \\
\hline Coastal & Control & 15 & 9.4 & 2.9 & 0.12 & 0.19 \\
\hline Offshore & Control & 11 & 11.7 & 1.9 & 0.15 & 0.25 \\
\hline Coastal & Organic enrichment & 16 & 13.1 & 5.2 & 0.18 & 0.29 \\
\hline Offshore & Organic enrichment & 9 & 9.2 & 2.3 & 0.12 & 0.18 \\
\hline \multicolumn{7}{|c|}{ Amphiura chiajei } \\
\hline Coastal & Control & 16 & 1.7 & 0.7 & 0.026 & 0.02 \\
\hline Offshore & Control & 16 & 1.3 & 0.6 & 0.020 & 0.02 \\
\hline Coastal & Organic enrichment & 11 & 2.3 & 0.9 & 0.035 & 0.03 \\
\hline Offshore & Organic enrichment & 15 & 2.1 & 0.9 & 0.032 & 0.03 \\
\hline
\end{tabular}
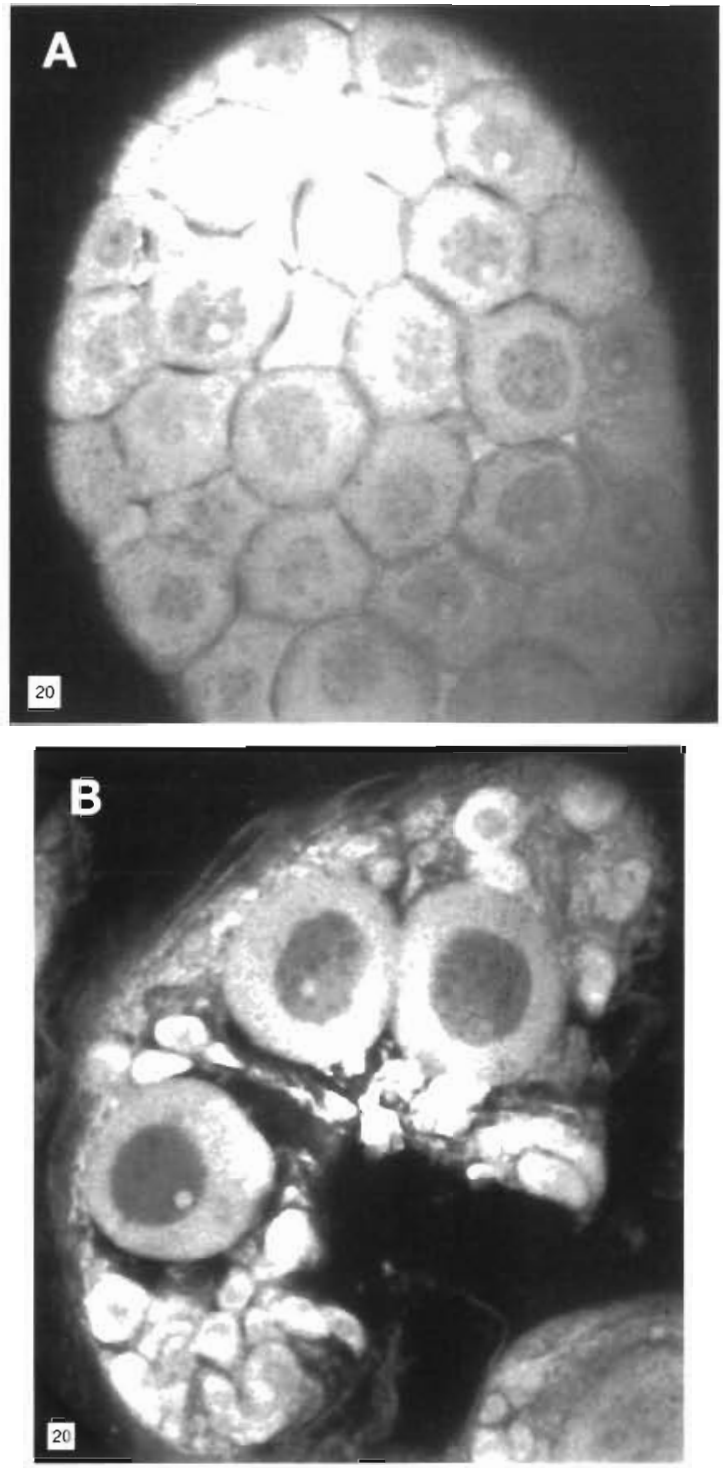

\section{Differences between sites}

The major difference between the 2 sediments was the striking difference in biomass and density of brittle stars. The dense population of Amphiura filiformis (3300 ind $\mathrm{m}^{-2}$ ) at the offshore site is among the highest abundance observed in the Kattegat-Skagerrak. This site is situated on the western slope of a $90 \mathrm{~m}$ deep trench in the Skagerrak. Rosenberg (1995) has recently investigated this area and suggested that its extreme macrofaunal density is correlated to an important near-bottom particle transport, rich in organic matter, offering particularly favourable conditions for suspension feeders such as A. filiformis. The coastal site situated west of Göteborg is a shallower $(21 \mathrm{~m})$ estuarine site. Seciment toxicity and elevated levels of contaminants have been reported in this area (Dave \& Dennegård 1994, Dave \& Nilsson 1994). In this study, however, the contaminant content was not higher than at the offshore site and none of the toxicity tests performed showed any difference between the sites. In the controls, receiving only natural unfiltered sea water, both Amphiura species regenerated their arm, indicating that both species could either collect some food from the sediment and the overlying water, or allocate previous body reserves into arm regeneration. However, no difference in growth between sites was observed.

Fig. 4. (A) Confocal Laser Scanning Microscopy (CLSM) picture of female Amphiura filiformis gonad in prematuration stage. Section $5 \mu \mathrm{m}$ thick. Scale quadrat in bottom left corner is $20 \times 20 \mu \mathrm{m}$. (B) Femali Amphiura chiajei gonad in postshedding stage, with remaining large eggs from previous spawning. Section $5 \mu \mathrm{m}$ thick. Scale quadrat in bottom left corner is $20 \times 20 \mu \mathrm{m}$ 


\section{Response to organic enrichment}

The rate of food supply afforded by the external environment may limit growth. However, in excess of food, as during a spring bloom sedimentation, growth may still be rate-limited due to the benthic animals' food processing rate rather than supply (Jumars \& Wheatcroft 1989). Increased growth was observed in the coastal site sediment in response to the organic enrichment. When dividing the organic matter input per Amphiura filiformis, the supply was ca 10 times higher in the coastal compared to the densely populated offshore sediment. The most probable explanation for the observed lower growth rate in the offshore site sediment when supplied with organic enrichment is a negatively density-dependent effect on growth indicative of strong competition for food in that sediment. A similar negatively density-dependent growth has also been observed in the facultative deposit feeding bivalve Macoma balthica, but not in the obligate suspension feeding Cerastoderma edule (Kamermans et al. 1992). Josefson (1995) estimated somatic growth rates of $A$. filiformis, from oral width, over a $143 \mathrm{~d}$ interval and found density-independent growth despite high densities at some of the sites investigated. However, as the density of natural populations of $A$. filiformis is likely structured by food supply (Pearson et al. 1985, Pearson \& Rosenberg 1987, Josefson 1990, Josefson et al. 1993), the food supply per A. filiformis may not necessarily differ, which could explain why Josefson (1995) did not observe any density dependence.

Contrary to many previous organic enrichment experiments (e.g. Graf 1987, van Duyl et al. 1992, Osinga et al. 1995), the added organic matter was not frozen, crushed or heated but constituted of naturally aggregated diatoms. This was done to mimic natural conditions in which the spring phytoplankton bloom is often composed of diatoms, which settle rapidly as a pulse of aggregates onto the sediment surface (Hargrave 1980, Smetacek \& Hendrikson 1985). This settling material has been shown to have a high nutritional value (Tenore 1988), reflected by a low C:N ratio, and to cause a rapid and short-lasting increase of benthic metabolic processes (Graf et al. 1983, Christensen \& Kanneworff 1985, Graf 1987). Values of sedimenting organic carbon during a spring bloom in the KattegatSkagerrak are scarce. However, the amount of organic carbon added in the present study, $17 \mathrm{~g} \mathrm{C} \mathrm{m}^{-2}$ (68 d), is within the range of values of spring input from sediment trap and in situ measurements from $4.6 \mathrm{~g} \mathrm{C} \mathrm{m}^{-2}$ (25 d) in the northern North Sea (Davies \& Payne 1984), 20 to $26 \mathrm{~g} \mathrm{C} \mathrm{m}^{-2}$ (55 d) in the southern Kattegat (Christensen \& Kanneworff 1985), to $70 \mathrm{~g} \mathrm{C} \mathrm{m}^{-2}$ (50 d) in the western Kiel Bight (Graf et al. 1983). Benthic organisms have also been suggested to be nitrogen limited rather than limited by the supply of organic carbon (Findlay 1982). The seasonal pattern of spring bursts in benthic metabolism may in fact be triggered by the quality of the organic supply, especially the presence of limiting micronutrients (essential amino acids and polyunsaturate fatty acids) in diatoms, rather than by the quantity of macronutrients (organic carbon and nitrogen) (Tenore 1988, Marsh \& Tenore 1990). In this study, the response to the addition of diatoms was manifested in an increased activity of the 2 Amphiura species. The increased growth of arm length and disk size of $A$. filiformis and disk size of $A$. chiajei due to the organic enrichment in the coastal site (Fig. 3A, B and C) shows that this short-term organic enrichment can be rapidly converted into growth of the 2 Amphiura species. Oocyte size was also positively correlated with regenerated arm length for both species; this indicates that germinal growth followed changes in somatic growth and possibly also depended on food availability. The interactive growth patterns suggest densitydependent growth due to intraspecific competition with food as the limiting factor, which is also supported by the observed faster processing of the aggregated phytoplankton in the offshore sediment. Competition for space in the densely populated offshore site sediment may also have occurred; this in turn could have lead to sub-optimal feeding behaviour and possibly slower growth in this sediment.

\section{Differences between species}

Regenerated arm length of Amphiura chiajei increased in sediments from both sites when phytoplankton was given. The slower regeneration rate of $A$. chiajei compared to $A$. filiformis is supported by Buchanan (1964), who estimated growth rate, longevity and oxygen consumption of the 2 species. He found that $A$. filiformis exceeded $A$. chiajei in oxygen consumption by a factor of 5 , and concluded that $A$. filiformis had a higher metabolic rate and food requirement than $A$. chiajei. As the added organic material in this study was allowed to sediment out and was available as deposited material for both species, the increase in growth rate in both species was due to efficient deposit feeding of the phytoplankton aggregates. However, suspension feeding may have contributed to maintainance metabolism in A. filformis, as this species has the capacity of switching from deposit to suspension feeding (Buchanan 1964, Woodley 1975) and theoretically can balance growth and respiration by suspension feeding on available seston (Loo et al. 1996). The suspended matter in the unfiltered seawater in this experiment was probably available to $A$. filiformis, as raised arms into the water column, indica- 
tive of filter feeding activity, were observed during the whole experiment in all treatments. The faster regeneration rate and metabolism of $A$. filiformis compared to $A$. chiajei may thus be attributed to a more efficient and competitive feeding strategy in $A$. filiformis compared to the obligate deposit feeding $A$. chiajei. Another possible explanation of the difference in regeneration rate between the 2 species could be that energy allocation is more important in early arm regeneration for $A$. chiajei, so that early regeneration may be independent of external food supply. This explanation is supported by Dobson et al. (1991), who, reporting about another amphiurid brittle star, found that internal reserves from the disk, oral frame region and distal arm regions of the body were used in early disk regeneration.

The regeneration rates of Amphiura filiformis, ranging from 2.9 to $3.8 \mu \mathrm{g}$ dry wt $\mathrm{arm}^{-1} \mathrm{~d}^{-1}$ in this experiment (Table 3) are within the range reported by Salzwedel $(7.1 ; 1974)$, Andreasson $(4.8 ; 1990)$, and Nilsson \& Sköld $(3.7 ; 1996)$, but lower than $82 \mu \mathrm{g}$ dry wt arm $^{-1} \mathrm{~d}^{-1}$ reported by $\mathrm{O}^{\prime}$ Connor et al. (1986)

\section{Consequences of increased levels of organic matter to Amphiura filiformis populations}

Amphiura filiformis is one of the dominant species below the halocline in the Kattegat where densities of around 100 to 400 ind. $\mathrm{m}^{-2}$ are common (Pearson et al. 1985). A doubling of primary production has occurred in the Kattegat since the 1950s (Richardson \& Heilmann 1995). When food supply increases, Amphiura spp. populations can respond in alternative ways, e.g. by means of increased new recruits and growth; still the populations may be regulated by density independent factors such as predation. An increase in both somatic and germinal biomass was observed for both species in this study; however, the ultimate fate of this biomass increase on the population level is beyond the scope of this study. Nilsson \& Sköld (1996) investigated effects of hypoxia on growth rates of $A$. filiformis. To estimate the yearly possible loss in production of regenerated arms due to the frequent autumnal hypoxia observed in the Kattegat they used a $3000 \mathrm{~km}^{2}$ area, and 280 ind. $\mathrm{m}^{-2}$ as an approximate mean abundance of $A$. filiformis. Using similar figures of abundance and area, an estimate of the possible effect of an organic enrichment of $16.8 \mathrm{~g} \mathrm{C} \mathrm{m}^{-2}$ over 2.5 mo on arm growth of this hypothetical $A$. filiformis population in the Kattegat can be calculated. This gives an increased arm length of $39 \%$ compared to the controls in this experiment (calculated from Table 3). If the volume of an arm is considered to be proportional to its weight and to have the form of a cylinder, an increase in length of the arm is directly proportional to the increase in volume and weight; thus the weight of the arm should increase by $39 \%$ due to the organic enrichment. Disk production, estimated by the disk volume increased about $12 \%$ in diameter (calculated from mean disk areas of $A$. filiformis). Analogously, the increase in volume of the Amphiura spp. disk, assuming it has the form of a cylinder, is directly proportional to the square of the diameter, thus $25 \%$. Skold et al. (1994) estimated total production to $9.46 \mathrm{~g}$ dry wt $\mathrm{m}^{-2}$ for a population of that density. Thirteen percent of that was due to arm regeneration and $69 \%$ due to disk growth. Combining these patterns of growth with effects on arm regeneration and disk growth due to the organic enrichment in this study increased growth in the Kattegat area $\left(3000 \mathrm{~km}^{2} ; 280\right.$ ind. $\mathrm{m}^{-2}$ ) are estimated to 301 and 1041 metric tonnes due to arm regeneration and disk growth, respectively. A possible net result over a year of an increased spring bloom sedimentation (Richardson \& Heilmann 1995), followed by autumn hypoxia (Rosenberg et al. 1992) in the Kattegat, can thus be estimated. Considering the increase due to arm regeneration (301 metric tonnes) and recalling the comparable loss estimated by Nilsson \& Sköld (1996) (81 to 145 metric tonnes), increasing biomass of A. filiformis during spring bloom sedimentation probably stimulates secondary production more than autumn hypoxia (1.8 to $2.7 \mathrm{mg} \mathrm{O}_{2} \mathrm{l}^{-1}$ ) reduces it, at least in terms of arm regeneration. Consequently, a positive correlation between primary production and adult biomasses of this species can be expected assuming other regulating factors, e.g. sub-lethal predation, to be constant. This is in accordance with the reports of increased growth patterns, abundance and biomass of A. filiformis, in some areas of the Kattegat and the Skagerrak (Pearson et al. 1985, Rosenberg et al. 1987 , Josefson 1990, Josefson \& Jensen 1991, 1992, Josefson et al. 1993). However, as evident from areas where mortality is high due to severe autumn hypoxia, this biostimulating effect of eutrophication may drastically switch to catastrophic events of high mortality if the community's increased $\mathrm{O}_{2}$ demand is not compensated (Rosenberg \& Loo 1988, Baden et al. 1990, Rosenberg et al. 1992).

\section{CONCLUSION}

This study indicates that a short-term organic enrichment, on the order of magnitude of and with the same quality as sedimenting matter during a spring bloom, significantly increases secondary production measured as arm regeneration, disk growth and oocyte development of dominant macrofauna, i.e. Amphiura filifomis and Amphiura chiajei. The amplitude of the 
response of $A$. filiformis growth rate to an organic enrichment also seems to be correlated to abundance and biomass and suggests negatively density-dependent growth, indicative of food or space competition.

It was also found that the opportunistic feeding Amphiura filiformis has a higher regeneration rate compared to the strictly deposit feeding Amphiura chiajei.

Acknowledgements. We express our gratitude to the staff at the Marine Research Station Solbergstrand, especially Einar Johannessen for technical assistance and Norwegian Institute for Water Research (NIVA) for providing excellent experimental facilities. We also thank Anna Lundberg, Hans Nilsson, Robert Bazin, Mats Carlsson, Anders Svensson, Vanessa Salin and the crew of RV 'Trygve Braarud' for field and laboratory assistance, Torsten Källqvist (NIVA) for providing algae cultures and toxicity testing (Nitocra spinipes). Anders Sjölin (Toxicon $A B$ ) for help with toxicity testing (Microtox ${ }^{8}$ ), Margit Fredrikson (Department of Systematic Botany, Göteborg University) for help with Confocal Laser Scanning Microscopy, Eva Brorström-Lundén (Swedish Environmental Research Institute) for chemical analyses. We also thank Rutger Rosenberg, Lars Förlin, Peter Tiselius, Iain Wilkie and 4 anonymous referees for fruitful comments on earlier drafts of this manuscript. This study was partially financed by the Swedish Environmental Protection agency (SNV) grant no. 5332341-6 and grant no. 12227, Royal Norwegian Council for Scientific and Industrial Research (NTNF) grant no. 29820, Marine Research Centre at Göteborg University, Nordic Council for Marine Biology, Nordisk Forskerutdanningsakademi (NorFA) and Paul och Marie Berghaus vetenskapsfond

\section{LITERATURE CITED}

Andreasson M (1990) Regenerationshastighet hos Amphiura filiformis (Ophiuroidae: Echinodermata). BSc thesis, University of Göteborg (in Swedish)

Ankar S (1980) Growth and production of Macoma balthica (L.) in a northern Baltic soft bottom. Ophelia (1):31-48

Ansell AD (1974) Seasonal changes in biogeochemical composition of the bivalve Abra alba from the Clyde Sea area. Mar Biol 25:13-20

Baden SP, Loo LO, Pihl L, Rosenberg R (1990) Effects of eutrophication on benthic communities including fish: Swedish west coast. Ambio 19:113-122

Balzer W (1984) Organic matter degradation and biogenic element cycling in a nearshore sediment (Kıel Bight). Limnol Oceanogr 29:1231-1246

Berge JA, Schaanning M, Bakke T, Sandøy KA, Skele GM, Ambrose WGJ (1986) A soft-bottom sublittoral mesocosm by the Oslofjord: description, performance and examples of application. Ophelia 26:37-54

Bowmer T (1982) Reproduction in Amphiura filiformis (Echinodermata: Ophuroldea): seasonality in gonad development. Mar Biol 69:281-290

Bowmer T, Keegan BF (1983) Field survey of the occurrence and significance of regeneration in Amphiura filiformis (Echinodermata: Ophiuroidea) from Galway Bay, west coast of Ireland. Mar Biol 74:65-71

Brorström-Lundén E (1995) Measurements of semivolatile organic compounds in air and deposition. PhD thesis, Göteborg University and Chalmers University of Technology, Sweden
Brouwer H, Murphy T, McArdle L (1990) A sediment contact bioassay with Photobacterium phosphoreum. Environ Toxicol Chem 9:1353-1.358

Buchanan JB (1964) A comparative study of some features of the biology of Amphura filiformis and Amphiura chiajei (Ophiuroidea) considered in relation to their distribution. J Mar Biol Ass UK 44:565-576

Christensen H, Kanneworff E (1985) Sedimenting phytoplankton as major food source for suspension and deposit feeders in the Oresund. Ophelia 24:223-244

Dave G, Dennegard B (1994) Sediment toxicity and heavy metals in the Kattegat and Skagerrak. J Aquat Eco Health 3:207-219

Dave G, Nilsson E (1994) Sediment toxicity in the Kattegat and Skagerrak. J Aquat Eco Health 3:193-206

Davies JM. Payne R (1984). Supply of organic matter to the sediment in northern North Sea during a spring phytoplankton bloom. Mar Biol 78:315-324

Dobson WE, Stancyk SE, Clements LA, Showman RM (1991) Nutrient translocation during early disk regeneration in the brittlestar Microphiopholis gracillima (Stimpson) (Echınodermata, Ophiuroidea). Biol Bull 180:167-184

Duineveld GCA, Noort GJv (1986) Observations on the population dynamics of Amphiura filiformis (Ophiuroidea: Echinodermata) in the southern North Sea and its exploitation by the dab, Limanda limanda. Neth J Sea Res 20:85-94

Duineveld GCA, van Noort GJ, Kok A (1992) Report on macrofaunal growth in a mesocosm experiment with single dosage and continuous feeding. In: van Duyl FC (ed) Benthic response to eutrophication in manipulated marine sandy sediments. Neth Inst Sea Res Publ Ser, Den Burg, Texel, 1992-4, p 43-47

Duineveld G, Verburg P, Berghuis E, Kok A, van Noort GJ, de Wilde $P$ (1991) Metabolic responses of soft-bottom benthic mesocosms to enrichment and food deprivation. In: van Duyl FC (ed) The applicability of mesocoms in North Sea eutrophication studies. Mesocosm research 1989. Neth Inst Sea Res Publ Ser, Den Burg, Texel, 1991-5, p 87-98

Fenaux L (1970) Maturation of the gonads and seasonal cycle of the planktonic larvae of the ophiuroid Amphiura chiajei Forbes. Biol Bull 138:262-271

Fenchel TM, Riedl RJ (1970) The sulfide system: a new biotic community underneath the oxidized layer of marine sand bottoms. Mar Biol 7:255-268

Findlay SEG (1982) Effect of detrital nutritional quality on population dynamics of a marine nematode (Diplolaimella chitwoodi). Mar Biol 68:223-227

Fredriksson M (1991) Embryology of the orchidaceae. A study using confocal scanning laser microscopy PhD thesis, Göteborg University

Graf G (1987) Benthic energy flow during a simulated autumn bloom sedimentation. Mar Ecol Prog Ser 39:23-29

Graf G (1992) Benthic-pelagic coupling: a benthic view. Oceanogr Mar Biol Annu Rev 30:149-190

Graf G. Bengtsson W, Diesner U, Schulz R, Theede H (1982) Benthic response to sedimentation of a spring phytoplankton bloom: process and budget. Mar Biol 67:201-208

Graf G, Schulz R, Peinert R, Meyer-Reil LA (1983) Benthic response to sedimentation events during autumn to spring at a shallow-water station in the western Kiel bight I. Analysis of processes on a community level. Mar Biol 77 : 235-246

Grassle JF, Grassle JP, Brown-Leger LS, Petrecca RF, Copley NJ (1985) Subtidal macrobenthos of Narragansett Bay, field and mesocosm studies of the effects of eutrophication and organic input on benthic populations. In: Gray JS, 
Christiansen ME (eds) Marine biology of polar regions and effects of stress on marine organisms. John Wiley \& Sons Ltd, New York, p 421-434

Hargrave BT (1980) Factors affecting the flux of organic matter to sediments in a marine bay. In: Coull KRTBC (ed) Marine benthic dynamics. University of South Carolina Press, Columbia, p 243-263

Harris RN (1989) Nonlethal injury to organisms as a mechanism of population regulation. Am Nat 134(6):835-847

Hedges Jl, Stern JH (1983) Carbon and nitrogen determinations of carbonate-containing solids. Limnol Oceanogr 29. $657-663$

Henrichs SM. Doyle AP (1986). Decomposition of ${ }^{14} \mathrm{C}$-labeled organic substances in marine sediments. Limnol Oceanogr 31:765-778

Herr JM Jr (1971) A new clearing-squash technique for the study of ovule development in angiosperms. Am J Bot 58 $785-790$

Josefson AB (1990) lncrease of benthic biomass in the Skagerrak-Kattegat during the 1970 s and 1980 -effects of organic enrichment. Mar Ecol Prog Ser 66:117-130

Josefson AB (1995) Large-scale estimate of somatic growth in Amphiura filformis (Echinodermata: Ophiuroidea). Mar Biol 124:435-442

Josefson AB, Jensen JN (1991) Benthic dynamics in the Skagerrak-Kattegat area suggest major importance of large-scale, pelagic production related factors. COST 647 Coastal benthic ecology activity report 1988-1991 Coopération européenne dans la domaine de la Recherche Scientifique et Technique, Galway, Ireland

Josefson AB, Jensen JN (1992) Growth patterns of Amphiura filiformis support the hypothesis of organic enrichment in the Skagerrak-Kattegat area. Mar Biol 112:615-624

Josetson AB, Jensen JN, Aertebjerg G (1993) The benthos community structure anomaly in the late 1970 s and early 1980 s - a result of a major food pulse. J Exp Mar Biol Ecol $172: 31-45$

Jumars PA, Wheatcroft RA (1989) Responses of benthos to changing food quality and quantity, with focus on deposit feeding and bioturbation. In: Berger WH, Smetacek VS, Wefer $G$ (eds) Productivity of the ocean: present and past. John Wiley \& Sons Ltd, New York, p 235-253

Kamermans P, van der Veer HW, Karczmarski L, Doeglas GW (1992) Competition in deposit and suspension feeding bivalves: experiments in controlled outdoor environments. J Exp Mar Biol Ecol 162:113-135

Kanneworff E, Christensen H (1986). Benthic community respiration in relation to sedimentation in the Oresund Ophelia 26:269-284

Kelly JR, Nixon SW (1984) Experimental studies of the effect of organic deposition on the metabolism of a coastal marine bottom community. Mar Ecol Prog Ser 17:157-169

Kiørboe I, Lundsgaard C, Olesen M, Hansen JLS (1994) Aggregation and sedimentation processes during a spring phytoplankton bloom: a field experiment to test coagulation efficiency. J Mar Res 52:297-323

Loo LO, Jonsson P, Sköld M, Karlsson Ö (1996) Passive suspension feeding in Amphiura filiformis (Echinodermata: Ophiuroideal: feeding behaviour in flume flow and potential feeding rate of field populations. Mar Ecol Prog Ser $139: 143-155$

Lopez GR, Levinton JS (1987) Ecology of deposit-feeding animals in marine sediments. Q Rev Biol 62:235-260

Marsh AG, Tenore KT (1990). The role of nutrition in regulating the population dynamics of opportunistic, surface deposit feeders in a mesohaline community. Limnol Oceanogr $35: 710-724$
Munday BW (1993) Field survey of the occurrence and significance of regeneration in Amphiurd chiajei (Echinodermata, Ophiuroldea) from Kullary Harbour, West Coast of Ireland. Mar Biol 115:661-668

Nicolaisen W, Christensen $H$ (1986) Pelagic turnover and transport to the bottom of particulate material in the Northern Oresund. Ophelia 26:317-332

Nilsson HC, Sköld M (1996) Arm regeneration and spawning behaviour in the brittle star Amphiura filuformis $1 O$. $F$. Müller) during hypoxia. J Exp Mar Biol Ecol 199:193-206

O'Connor B, Bowmer T. Grehan A (1983) Long-term assessment of the population dynamics of Amphiura filiformis (Echinodermata: Ophiuroidea) in Galway Bay (west coast of Ireland). Mar Biol 75:279-328

O'Connor B, Bowmer T, McGrath D, Raine R (1986) Energy flow through an Amphiura filiformis (Ophiuroidea: Echinodermata) population in Galway Bay, west coast of Ireland: a preliminary investigation. Ophelia 26:351-357

Osinga R, Lewis WE, Wopereis JLM, Vriezen C, Van Duyl FC (1995) Effects of the sea urchin Echinocardium cordatum on oxygen uptake and sulfate reduction in experimental benthic systems under increasing organic loading. Ophelia 41:221-236

Pearson TH, Josefson AB, Rosenberg R (1985) Petersen's benthic stations revisited. I. Is the Kattegat becoming eutrophic? J Exp Mar Biol Ecol 92:157-206

Pearson TH, Rosenberg R (1987) Feast and famine: structuring factors in marine benthic communities. In: Gee JHR, Giller PS (eds) The 27th symposium of the british ecological society, Aberystwyth 1986. Blackwell Scientific Publications, Oxford, p 373-395

Richardson K, Heilmann JP (1995) Primary production in the Kattegat: past and present. Ophelia 41:317-328

Rosenberg R (1.995) Benthic marine fauna stuctured by hydrodynamic processes and food availability. Neth $J$ Sea Res 34(4):303-317

Rosenberg R, Elmgren R, Fleisher $\mathrm{S}$, Jonsson P, Persson G, Dahlin $H$ (1990) Marine eutrophication case studies in Sweden-a synopsis. Ambio 19:102-108

Rosenberg R, Gray JJ, Josefson AB, Pearson TH (1987) Petersen's benthic stations revisited II. Is the Oslofjord and eastern Skagerrak enriched? J Exp Mar Biol Ecol 105: $219-251$

Rosenberg R, Loo LO (1988) Marine eutrophication induced oxygen deficiency: effects on soft bottom fauna, western Sweden. Ophelia 29:213-225

Rosenberg R, Loo LO, Möller P (1992). Hypoxia, salinity and temperature as structuring factors for marine benthic communities in a eutrophic area. Neth J Sea Res 30:121-129

Salzwedel H (1974) Arm regeneration bei Amphiura filiformis (Ophiuroidea). Veröff Inst Meeresforsch Bremerhaven 14 $161-167$

SIS (1985) Water quality - determination of the inhibition of the mobility of Daphnia magna Straus (Cladophora, Crustacea). Swedish Standard SS 028180

Skei J, Pedersen A, Berge JA, Bakke T, Næes C (1987) Indre Sorfjord. Sedimentenes betydning for metallforurensningen i miljøet. Muligheter og behov for tiltak. Fase 2. Kvantifisering av utlekking av tungmetaller fra forurensade sedimenter. Norwegian Institute for Water Research Report 1-87 (in Norwegian)

Sköld M, Loo L.O, Rosenberg R (1994) Production, dynamics and demography of an Amphiura filiformis population. Mar Ecol Prog Ser 103:81-90

Sköld M, Rosenberg R (1996) Significance of arm regeneration in seven species of Ophiuroidea (Echinodermata) from European sea areas. J Sea Res 35(4):353-362 
Smetacek VS (1980) Annual cycle of sedimentation in relation to plankton ecology in Western Kiel Bight. Ophelia 1. $65-76$

Smetacek VS, Hendrikson P (1985) Role of sinking in diatom life-history cycles: ecological, evolutionary and geological significance. Mar Biol 84:239-251

Snedecor GW, Cochran WG (1967) Statistical methods, 6th edn. University of lowa Press, Ames

Sokal RR, Rohlf FJ (1995) Biometry, 3rd edn. WH Freeman \& Co, New York

Tenore KR (1988) Nitrogen in benthic food chains. In: Sorensen $J$, Blackburn TH (eds) Nitrogen cycling in coastal

This article was presented by J. D. Gage (Senior Editorial Advisor), Oban, United Kingdom marıne environments. John Wiley \& Sons Ltd, New York, p 191-206

van Duyl FC, Kop AJ, Kok A, Sandee AJJ (1992) The impact of organic matter and macrozoobenthos on bacterial and oxygen variables in marine sediment boxcosms. Neth $J$ Sea Res 29:343-355

Webb DG, Montagna PA (1993) Initial burial and subsequent degradation of sedimented phytoplankton-relative impact of macrobenthos and meiobenthos. J Exp Mar Biol Ecol 166:151-163

Woodley JD (1975) The behaviour of some amphiurid brittle stars. J Exp Mar Biol Ecol 18:29-46

Manuscript first received: November 3, 1995

Revised version accepted: June 12, 1996 